\title{
In vitro Biocompatibility Evaluation of Anodic Alumina Substrates with Electrochemically Embedded Silver
}

\author{
DENITSA KIRADZHIYSKA ${ }^{1 *}$, TSVETELINA BATSALOVA ${ }^{2}$, BALIK DZHAMBAZOV ${ }^{2}$, \\ ROSITSA MANCHEVA ${ }^{1}$ \\ ${ }^{1}$ Medical University of Plovdiv, Faculty of Pharmacy, Department of Chemical Sciences, 15A V. Aprilov blvd, 4000 Plovdiv, \\ Bulgaria \\ 2Plovdiv University "Paisii Hilendarski”, Department of Developmental Biology, 24 Tsar Assen St, 4000 Plovdiv, Bulgaria
}

\begin{abstract}
Anodic aluminum oxide films modified by silver incorporation (Al-O-Ag) under specific electrodeposition conditions were produced and their biocompatibility was analyzed by in vitro assays using mammalian cell lines. The results obtained demonstrate that Al-O-Ag substrates are well tolerated by human dermal fibroblasts. The alumina pads doped with silver for short time-period (30 seconds) showed the highest biocompatibility among all modified metal substrates and in comparison with three dental alloys.
\end{abstract}

Keywords: aluminum oxide layers, electrochemical silver incorporation, mammalian cell lines, in vitro biocompatibility

\section{Introduction}

Aluminum oxide $\left(\mathrm{Al}_{2} \mathrm{O}_{3}\right)$ is extensively used in medical devices manufacturing. There are reports stating that this material is inert in biological systems and therefore it is appropriate for patients with sensitivity to different metallic alloys [1-2].

By electrochemical processes layers of $\mathrm{Al}_{2} \mathrm{O}_{3}$ with desirable thickness can be produced on the surface of aluminum and its alloys, which are available on the market and have a reasonable price [3]. These oxide films are able to passivate the metal surface and do not allow any further interactions with the environment. Electrochemical oxidation in sulfuric, oxalic and phosphoric acids usually leads to the formation of porous structures [4]. The pores of the as obtained oxide films can be filled with different metals like $\mathrm{Co}$ [5], $\mathrm{Cu}$ [6], $\mathrm{Ni}$ [7], etc. These metal-doped alumina layers are used for decorative and environmental applications but surface modifications can also improve the corrosion resistance and bactericidal properties of the metal pad [8-10]. It is well known that silver posses good antibacterial properties [11]. Silver particles incorporated in aluminum oxide coatings exhibit excellent inhibitory effect on P. aeruginosa, S. faecalis, S. aureus [12] and A. fumigatoslawus, G. candidumlawus, E. coli, $M$. luteus [13]. However, studies with different mammalian cell lines demonstrate that nanosized silver can exhibit toxicity to mouse lung, liver and stem cells, human and mouse fibroblasts, as well as human carcinoma cells [14]. Taking into account these considerations, the current study aimed to investigate the biocompatibility of anodic aluminum oxide with electrochemically embedded silver particles (Al-O$\mathrm{Ag})$.

\section{Method and materials \\ Preparation of Al-O-Ag samples}

In the current work technically pure aluminum alloy (EN AW 1050A) with $\mathrm{Al}$ content of $99.5 \%$ was used. Specimens with dimensions $20 \mathrm{~mm}$ x $20 \mathrm{~mm}$ x $0.5 \mathrm{~mm}$ were cut from the aluminum sheet. Prior to anodization, the initial air-formed oxide film was removed from the surface of the samples by immersing in a mixture of sodium hydroxide $\left(2 \mathrm{~g} . \mathrm{L}^{-1}\right)$ and sodium nitrate $\left(3 \mathrm{~g} \cdot \mathrm{L}^{-1}\right)$. After that the specimens were degreased in acetone, etched in a mixture of concentrated nitric acid and water (1:1) and finally electropolished using a mixture of concentrated perchloric acid and ethanol (1:4) at current density 0.15 A. $\mathrm{cm}^{-2}$ for $5 \mathrm{~min}$. After each step the samples were extensively rinsed in double-distilled water.

*email: denitsa.kiradzhiyska@gmail.com 
All solutions were prepared with analytical grade reagents and double-distilled water.

The anodization was conducted in $1.53 \mathrm{M}$ sulfuric acid solution at constant current density 0.015 A. $\mathrm{cm}^{-2}$ in a thermostated glass cell at $20 \pm 2^{\circ} \mathrm{C}$ for 25 and $50 \mathrm{~min}$. A two electrode cell was used with a lead plate as a counter electrode, placed symmetrically around the anode.

The electrochemical silver deposition process was carried out by $20 \mathrm{~V}$ alternating current (sinusoidal) polarization $\left(50 \mathrm{~Hz} \mathrm{AC}\right.$ frequency) in an electrolyte which consists of silver nitrate $\left(1.51 \mathrm{~g}\right.$. $\left.\mathrm{L}^{-1}\right)$ and boric acid $\left(45 \mathrm{~g} . \mathrm{L}^{-1}\right)$ at $20 \pm 2^{\circ} \mathrm{C}$ for different time-periods. The counter electrode was platinum mesh.

\section{Characterization of the obtained Al-O-Ag films}

To determine the anodic film thickness depending on the duration of the anodization morphological observations were performed by Scanning Electron Microscopy (SEM) using JEOL JSM 35 CF at different magnifications. For these analyses, cross-sections of alumina films were obtained.

The amount of the incorporated silver into the anodic films with different film thickness was determined by Inductively Coupled Plasma Optical Emission Spectroscopy (ICP-OES) using Prodigy 7 spectrometer (Teledyne Leeman Labs). For this purpose Al-O-Ag layers were dissolved in a mixture of concentrated nitric acid and water (1:1), at room temperature.

The surface characteristics of the aluminum pads were examined using Atomic Force Microscopy (AFM), performed by Easy Scan 2 (Nanosurf), equipped with TAP 190-Al G cantilever (Budget sensors). Work-zones with linear size of $49.5 \mu \mathrm{m}$ and 256 points per line of resolution were used.

\section{Cell lines and culture conditions}

Two mammalian cell lines were used in the present study: (1) NIH-3T3 (ATCC ${ }^{\circledR}$ CRL-1658 ${ }^{\mathrm{TM}}$, ECACC 93061524), a continuous cell line derived from NIH/Swiss mouse embryo and (2) F - a finite human dermal fibroblast line isolated from preputium. The cells were grown in Dulbecco's Modified Eagles's Medium (DMEM) (Sigma-Aldrich, Merck KGaA, Germany) supplemented with 10\% heatinactivated fetal calf serum (PAA Laboratories, Austria) and antibiotics $(100 \mathrm{U} / \mathrm{mL}$ penicillin and 100 $\mu \mathrm{g} / \mathrm{mL}$ streptomycin) (Sigma-Aldrich, Merck KGaA, Germany) under standard culture conditions $\left(37^{\circ} \mathrm{C}\right.$ temperature, $5 \% \mathrm{CO}_{2} / 95 \%$ atmospheric air mixture and high humidity). Prior to the biocompatibility assays, the cells were propagated in $75 \mathrm{~cm}^{2}$ culture flasks (TPP, Switzerland). At $80 \%$ confluency, the cells were detached using $0.2 \%$ trypsin- $0.53 \mathrm{mM}$ EDTA buffer solution. The concentration of viable cells was determined by the Trypan blue assay [15].

\section{In vitro biocompatibility assays}

Cells were seeded $\left(1 \times 10^{5}\right.$ cells $\left./ \mathrm{mL}\right)$ on 6 -well culture plates (TPP, Switzerland) and co-cultured for $48 \mathrm{~h}$ with the tested aluminum specimens - untreated aluminum alloy, anodized aluminum alloy with thickness of the anodic film $10 \mu \mathrm{m}$ or $20 \mu \mathrm{m}$ and Al-O-Ag pads, which were placed on the bottom of the wells. In control wells the cells were grown without metal substrate or with a glass coverslip. Three commercially available alloys used for dental reconstructions were also included in the evaluations: Phase-N Premium, Wirobond $\mathrm{C}$ and Crystalloy $\mathrm{M}$ alloys. The Phase- $\mathrm{N}$ Premium is a NiCrMo alloy, which contains Ni-61\%, Co-24\% and Mo-11\%. The main composition of Wirobond C is Co-63.3\%, Cr$24.8 \%, \mathrm{~W}-5.3 \%$. Crystalloy $\mathrm{M}$ is composed of Ni-64\%, Cr-25\%, Mo-6\%.

At the end of the incubation period, the test-substrates were removed from the culture plates and 5 $\mathrm{mg} / \mathrm{mL}$ MTT ([3-(4,5-dimethylthiazol-2-yl)-2,5-diphenyltetrazolium bromide]) solution was added to the cells to a final concentration of $0.5 \mathrm{mg} / \mathrm{mL}$. The cultures were incubated for $2-3 \mathrm{~h}$ at $37^{\circ} \mathrm{C}, 5 \% \mathrm{CO}_{2}$ and high humidity. The MTT assay was performed in accordance to the methodology described by Edmondson [16]. After incubation with MTT (Sigma-Aldrich, Merck KGaA, Germany), the culture medium was removed and the cells were washed with Dulbecco's phosphate-buffered saline (DPBS) (Gibco, Invitrogen, USA). Then, $1 \mathrm{~mL} /$ well dimethyl sulfoxide (DMSO) (Sigma-Aldrich, Merck KGaA Germany) volumes was added to the cells in order to dissolve the accumulated formazan product. The cultures were incubated with DMSO for $15 \mathrm{~min}$ at $37^{\circ} \mathrm{C}$. The amount of formazan extracted from the 
cells was measured spectrophotometrically at $570 \mathrm{~nm}$. The data obtained were used to calculate the percentage (\%) of cells that survive after co-culture with Al-O-Ag sample or dental alloy based on the following formula:

$$
\% \text { survival }=\frac{\text { A sample }}{\text { A control }} \times 100 \text {, where A means absorbance }
$$

\section{Results and discussions}

\section{Characteristics of the modified anodic layers}

It is well known that thicker oxide films exhibit better insulating properties. They are able to protect the aluminum substrates from the harmful effects of the environment. In order to determine the thickness of the obtained anodic films on the surface of the aluminum alloy SEM analysis was used. Figure 1 demonstrates that anodizing in $1.53 \mathrm{M}$ sulfuric acid solution for 25 min results in about $10 \mu \mathrm{m}$ thick oxide layers and for $50 \mathrm{~min}$ results in about $20 \mu \mathrm{m}$ thick oxide layers. The oxide film is evenly distributed on the whole surface of the metal pad.
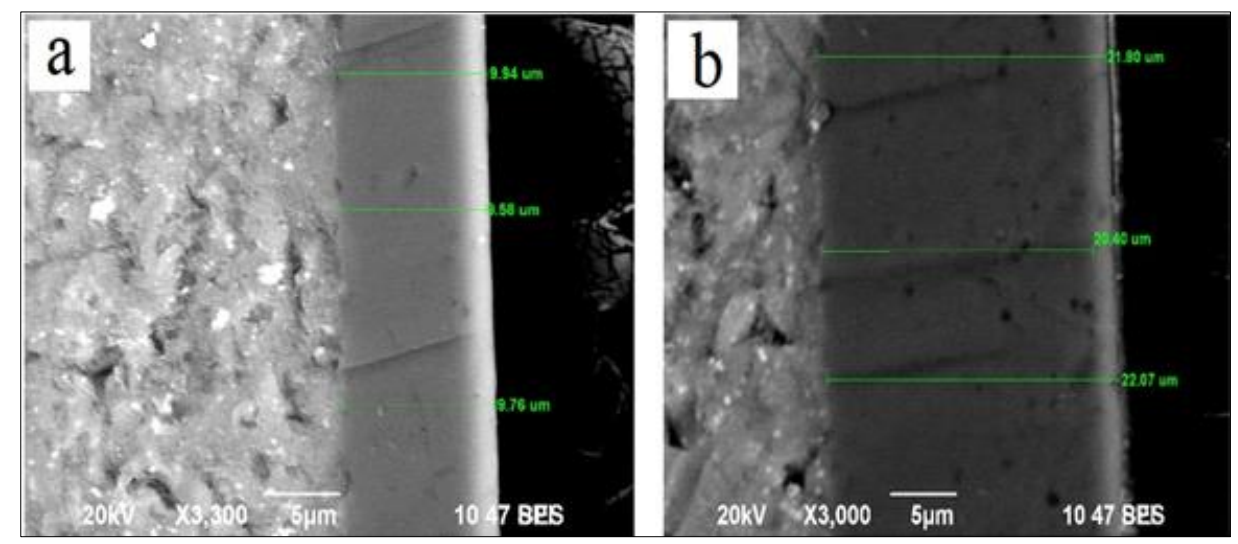

Figure 1. SEM images of the anodic films obtained after anodic oxidation for $25 \mathrm{~min}(\mathbf{a})$ and $50 \mathrm{~min}(\mathbf{b})$

The impact of the silver doped anodic films on the cell cultures growth rate will depend on their morphological characteristics and the concentration of the incorporated metal. Therefore, the determination of the $\mathrm{Ag}$ quantity depending on the oxide film thickness and on the duration of the deposition process is a task of great interest. The amount of the incorporated metal was determined using ICP-OES after dissolving the modified anodic layers. The acquired quantitative data are shown on Figure 2.

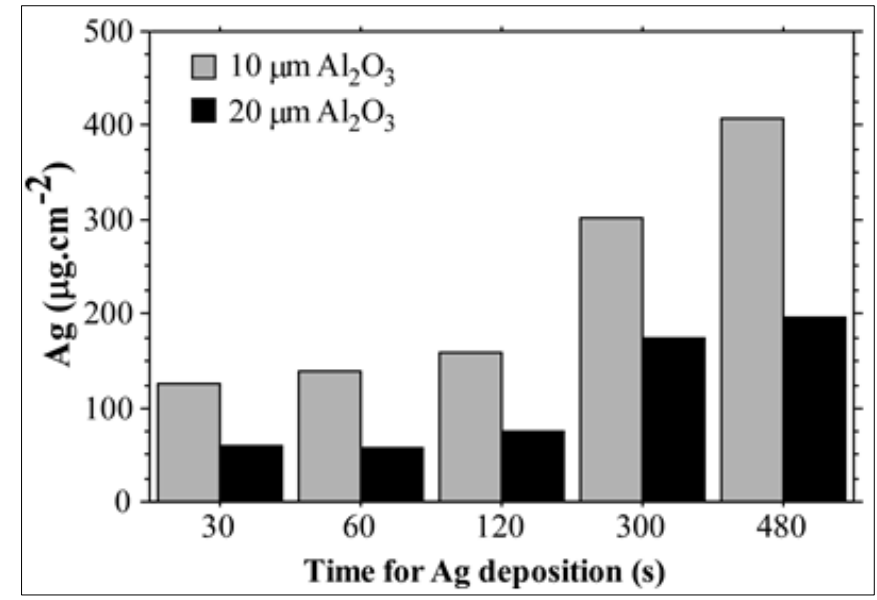

Figure 2. Dependence between the incorporated silver concentration and oxide film thickness vs. AC-incorporation time 
It is evident that the silver concentratiom is proportional to the duration of the incorporation process. Figure 2 also demonstrates that less silver is deposited into the thicker oxide films. This result is due to the better insulating properties of $20 \mu \mathrm{m}$ anodic layers that slow down the rate of the electrochemical silver deposition. In addition, it is believed that silver ions reduce easily on rough surfaces because of the enhanced electrical field by higher charge concentration [17]. The observations of anodic films surface morphology using the AFM method confirm that the roughness of the oxide films decreases with the increasing of their thickness. The obtained AFM images are shown on Figure 3.

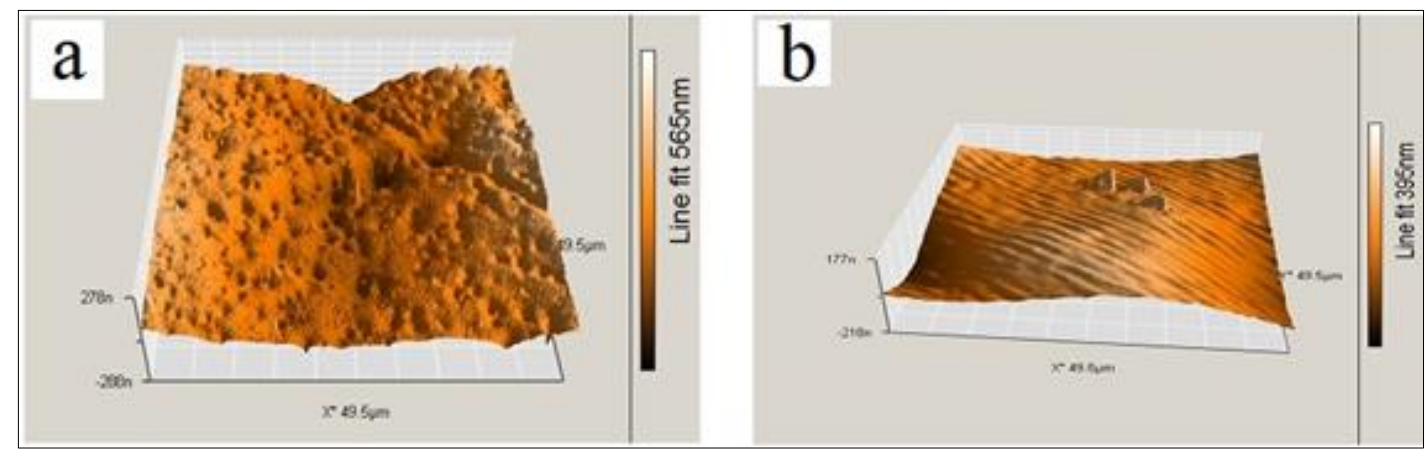

Figure 3. AFM images of the surface of samples with oxide film thickness of $10 \mu \mathrm{m}(\mathbf{a})$ and $20 \mu \mathrm{m}(\mathbf{b})$

The influence of silver deposition into the oxide layers with different thicknesses on the resulting morphology was also studied using atomic force microscopy. The obtained quantitative data reveal a certain trend of roughness increase with progression of the incorporation time irrespective of the film thickness. The results are represented in Table 1, where parameters are: Sa - average roughness value, $\mathrm{Sq}$ - square root roughness value, Sy - peak-valley height, Sp - peak height and Sv - valley depth.

Table 1. Roughness parameters as a function of silver incorporation time

\begin{tabular}{|c|c|c|c|c|c|c|}
\hline $\begin{array}{c}\text { Anodic film } \\
\text { thickness, } \\
{[\mu \mathrm{m}]}\end{array}$ & $\begin{array}{c}\text { Ag-incorporation time, } \\
{[\mathrm{s}]}\end{array}$ & $\begin{array}{c}\mathrm{Sa} \\
{[\mathrm{nm}]}\end{array}$ & $\begin{array}{c}\mathrm{Sq} \\
{[\mathrm{nm}]}\end{array}$ & $\begin{array}{c}\text { Sy } \\
{[\mathrm{nm}]}\end{array}$ & $\begin{array}{c}\text { Sp } \\
{[\mathrm{nm}]}\end{array}$ & $\begin{array}{c}\text { Sv } \\
{[\mathrm{nm}]}\end{array}$ \\
\hline 10 & 30 & 22.61 & 29.65 & 736.94 & 366.45 & -370.49 \\
\hline 10 & 480 & 124.43 & 153.53 & 1576.30 & 1024.00 & -551.53 \\
\hline 20 & 30 & 13.15 & 18.87 & 126.30 & 80.83 & -45.47 \\
\hline 20 & 480 & 89.58 & 123.64 & 904.99 & 566.02 & -338.97 \\
\hline
\end{tabular}

\section{In vitro biocompatibility analyses}

There is an abundance of research materials dealing with the antimicrobial properties of silver particles used for the creation of medical devices. At the same time, the biocompatibility testing of new materials is of a great importance to their potential application in clinical practice. All this impose the need for further examination of the cell survival rate depending on the silver concentration and morphology of the obtained Al-O-Ag layers.

For biocompatibility evaluations in vitro, cytotoxicity assays are generally preferred as an initial step that indicates the biological properties of candidate biomaterials. These tests are simple, fast and sensitive $[18,19]$. In fact, the International Standards Organization document (ISO 10993-5, 1992) classifies the cytotoxicity assay as the first stage in the sequence of biocompatibility tests [20]. The MTT assay is currently one of the most commonly used methods to test cell growth rate and toxicity following exposure to test-materials. Therefore, this cytotoxicity assay was applied in the present experiments and different anodized Al substrates with electrochemically embedded silver particles, aluminum alloy and dental alloys (Table 2) were tested. 
Table 2. Samples tested for in vitro biocompatibility

\begin{tabular}{|c|c|}
\hline Sample abbreviation & Sample type \\
\hline AA & aluminum alloy \\
\hline WB & Wirobond C \\
\hline PN & Phase-N Premium \\
\hline $\mathrm{CM}$ & Crystalloy M \\
\hline AAO-10 & $10 \mu \mathrm{m}$ anodic $\mathrm{Al}_{2} \mathrm{O}_{3}$ \\
\hline AAO-20 & $20 \mu \mathrm{m}$ anodic $\mathrm{Al}_{2} \mathrm{O}_{3}$ \\
\hline $10-1$ & $10 \mu \mathrm{m} \mathrm{Al}{ }_{2} \mathrm{O}_{3}$, silver deposition for $30 \mathrm{~s}$ \\
\hline $10-2$ & $10 \mu \mathrm{m} \mathrm{Al}{ }_{2} \mathrm{O}_{3}$, silver deposition for $60 \mathrm{~s}$ \\
\hline $10-3$ & $10 \mu \mathrm{m} \mathrm{Al}_{2} \mathrm{O}_{3}$, silver deposition for $120 \mathrm{~s}$ \\
\hline $10-4$ & $10 \mu \mathrm{m} \mathrm{Al}{ }_{2} \mathrm{O}_{3}$, silver deposition for $300 \mathrm{~s}$ \\
\hline $10-5$ & $10 \mu \mathrm{m} \mathrm{Al}{ }_{2} \mathrm{O}_{3}$, silver deposition for $480 \mathrm{~s}$ \\
\hline $20-1$ & $20 \mu \mathrm{m} \mathrm{Al}{ }_{2} \mathrm{O}_{3}$, silver deposition for $30 \mathrm{~s}$ \\
\hline $20-2$ & $20 \mu \mathrm{m} \mathrm{Al} \mathrm{O}_{3}$, silver deposition for $60 \mathrm{~s}$ \\
\hline $20-3$ & $20 \mu \mathrm{m} \mathrm{Al}{ }_{2} \mathrm{O}_{3}$, silver deposition for $120 \mathrm{~s}$ \\
\hline $20-4$ & $20 \mu \mathrm{m} \mathrm{Al}{ }_{2} \mathrm{O}_{3}$, silver deposition for $300 \mathrm{~s}$ \\
\hline $20-5$ & $20 \mu \mathrm{m} \mathrm{Al}{ }_{2} \mathrm{O}_{3}$, silver deposition for $480 \mathrm{~s}$ \\
\hline
\end{tabular}

Human and murine fibroblast cell lines are considered to represent sensitive tools for direct cytotoxicity and biocompatibility estimations of candidate biomaterials in vitro [21, 22]. Different mouse cell lines (L929, Balb/c 3T3, C3H-L, NIH-3T3) are commonly used for this aim [21, 23]. However, it is generaly accepted that cells originating from human tissue, in particular dermal fibroblasts and epidermal keratinocytes that participate in immune responses and wound healing, would provide more reliable results in cytotoxicity/ cytocompatibility tests of medical materials [23]. Thus, human dermal fibroblasts were chosen for the current study as a suitable in vitro test system for evaluation of the biocompatibility and cytotoxicity of Al-O-Ag substrates. In addition, the mouse fibroblast cell line NIH-3T3 was included in the experiments due to its common application in biocompatibility assays.

The results from the in vitro assays with human and mouse fibroblasts are shown on Figure 4. They demonstrate that Al-O-Ag samples with 10 and $20 \mu$ m thickness of the $\mathrm{Al}_{2} \mathrm{O}_{3}$ layer are well tolerated by human dermal fibroblasts and exert better in vitro biocompatibility than the unmodified aluminum alloy and the dental alloys PN and WB (Figure 4, B and D). A tendency for slightly reduced cell survival was evident for the samples with higher amount of deposited silver. The Al-O-Ag pads with deposited silver for 30 seconds showed the best percent survival of human dermal fibroblasts. The assays with NIH-3T3 cells demonstrated better biocompatibility of the samples with $10 \mu \mathrm{m}$ thickness of the $\mathrm{Al}_{2} \mathrm{O}_{3}$ layer (Figure 4, A and C). These data confirm previous results with immortalized precursor cells from human periodontal ligament (PDL) [24]. Interestingly, human dermal fibroblasts showed better in vitro biocompatibility with AAO-10 and AAO-20 than PDL cells. This difference in the response of two human cell lines could be due to the origin of the PDL cell line which has been generated by immortalization of periodontal ligament precursor cells. It is well known that the process of immortalization could affect normal cellular characteristics and behavior [25]. Therefore, a finite cell line derived from normal differentiated human fibroblasts represents a better model for biocompatibility evaluations.

For NIH-3T3 cells a good level of biocompatibility was detected only after co-culture with the dental material Christalalloy M, samples with $10 \mu \mathrm{m}$ oxide film thickness and electrochemically incorporated 
silver for short time-period (30 s). The mouse cell line also showed a tendency for reduction of cellular survival during co-cultivation with Al-O-Ag samples containing more electrochemically deposited silver (samples 10-4, 10-5, 20-3, 20-4, 20-5). This effect was detected with both mouse and human cell lines and suggests increased toxicity of the samples due to higher silver concentration of the tested specimens (Figure 2). It could be suggested that possible dissolution of silver ions could induce significant negative cellular effects. It has been shown that co-culture of NIH-3T3 cells with silver nanorods leads to cell membrane disruption probably due to release of silver ions. This induces actin depolymerization, impaired mitochondrial function, reactive oxygen species overproduction and as a result - cell death [26].

Overall, NIH-3T3 cells displayed higher sensitivity to Al-O-Ag, AAO samples and dental alloys which was indicated by lower percent cell survival compared to human dermal fibroblasts co-cultured with the same specimens (Figure 4). These data prove the need to use different cell lines in order to characterize in detail the biocompatibility of candidate medical materials and most importantly - the need to utilize normal human cells in these in vitro assays.
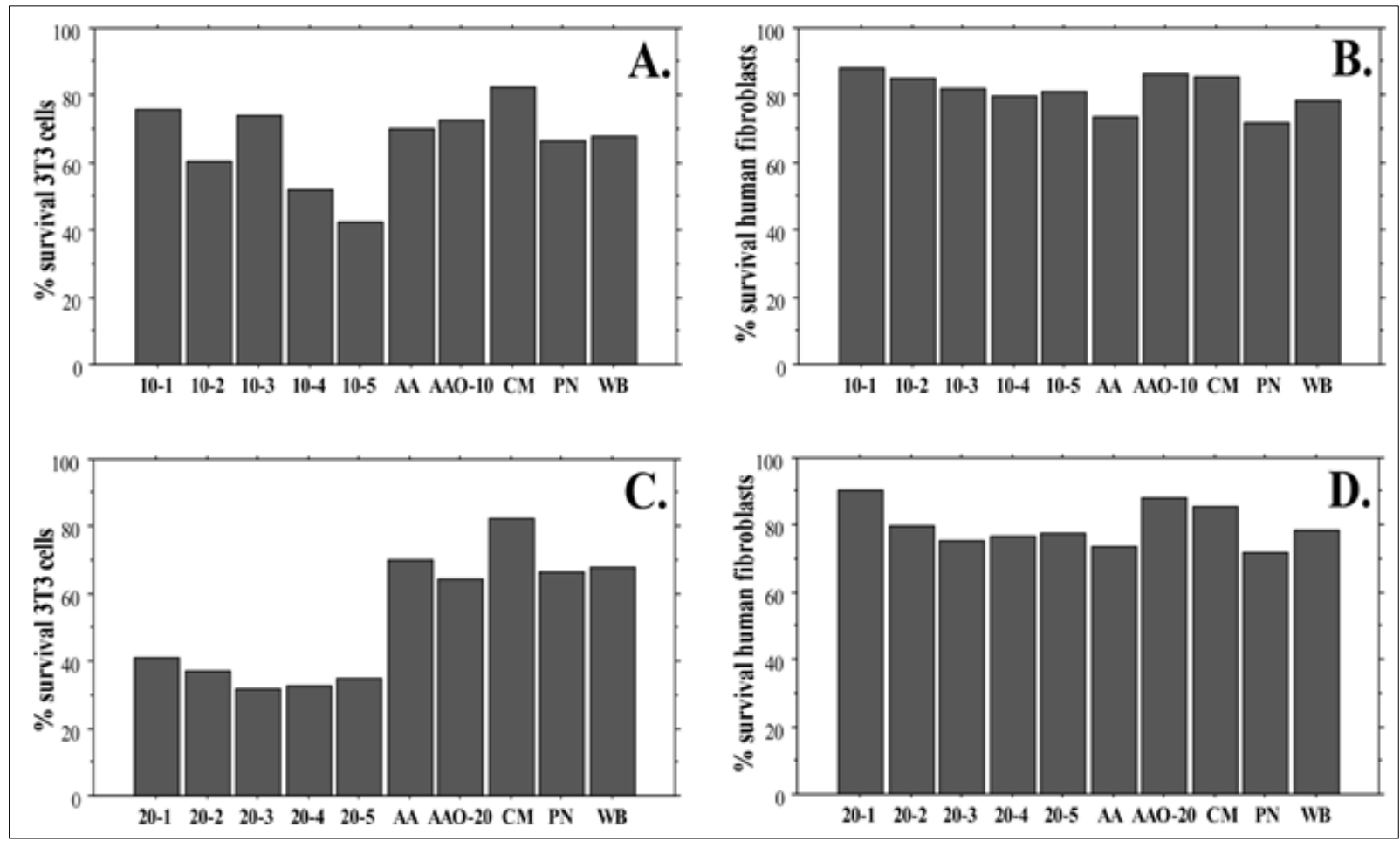

Figure 4. Results of in vitro assays with human fibroblasts and NIH-3T3 cells

\section{Conclusions}

The present study reports a specific method for production of anodic aluminum oxide substrates with electrochemically embedded silver, and their characterization by scanning electron microscopy, inductively coupled plasma optical emission spectroscopy, atomic force microscopy and in vitro biocompatibility assays with mammalian cells. The Al-O-Ag pads were well tolerated by human dermal fibroblasts while Al-O-Ag samples with $10 \mu \mathrm{m}$ thickness of the oxide film demonstrated better biocompatibility properties with NIH-3T3 cells. Alumina layers doped with silver for $30 \mathrm{~s}$ showed the highest biocompatibility among all tested metal pads and three dental alloys.

\section{References}

1. HENCH, L. L., Bioceramics: From Concept to Clinic, Journal of the American Ceramic Society, 74, No. 7, 1991, p. 1487. 
2. CHRISTEl, P., MEUNIER, A., DORLOT, J. M., CROLET, J. M., WITVOET, J., SEDEL, L., BOUTIN, P., Biomechanical compatibility and design of ceramic implants for orthopedic surgery, Annals of the New York Academy of Sciences, 523, No. 1, 1988, p. 234.

3. ZARASKA, L., KUROWSKA, E., SULKA, G. D., SENYK, I., JASKULA, M., The effect of anode surface area on nanoporous oxide formation during anodizing of low purity aluminum (AA1050 alloy), Journal of Solid State Electrochemistry, 18, No. 2, 2014, p. 361.

4. SULKA, G. D., Highly ordered anodic porous alumina formation by self-organized anodizing, chapter in: Nanostructured Materials in Electrochemistry, EFTEKHARI, A. (Ed.), volume 1, 2008, Wiley-VCH, p. 1.

5. SUN, M., ZANGARI, G., SHAMSUZZOHA, M., METZGER, R. M., Electrodeposition of highly uniform magnetic nanoparticle arrays in ordered alumite, Appl. Phys. Lett., 78, 2001, p. 2964.

6. PASTORE, G., MONTES, S., PAEZ, M., ZAGAL, J.H., Electrocolouring of anodized aluminium with copper: Effect of porous and barrier oxide film thicknesses, Thin Solid Films, 173, 1989, p. 299.

7. NIELSCH, K., WEHRSPOHN, R. B., BARTHEL, J., KIRSCHNER J., GOSELE U., FISCHER, S. F., KRONMULLER, H., Hexagonally ordered $100 \mathrm{~nm}$ period nickel nanowire arrays, Appl. Phys. Lett., 79, No. 9, 2001, p. 1360.

8. SCHIERHOLZ, J. M., LUCAS, L. J., RUMP, A., PULVERER, G., Efficacy of silver-coated medical devices, J. Hosp. Infect, 40, No. 4, 1998, p. 257.

9. GOSAU, M., HAUPT, M., THUDE, S., STROWITZKI, M., SCHMINKE, B., BUERGERS, R., Antimicrobial effect and biocompatibility of novel metallic nanocrystalline implant coatings, Journal of Biomedical Materials Research - Part B Applied Biomaterials, 104, No. 8, 2016, p. 1571.

10. CLOUTIER, M., MANTOVANI, D., ROSEI, F., Antibacterial Coatings: Challenges, Perspectives, and Opportunities, Trends Biotechnol., 33, No. 11, 2015, p. 637.

11. ABBASI, E., MILANI, M., FEKRI AVAL, S., KOUHI, M., AKBARZADEH, A., TAYEFI NASRABADI, H., NIKASA, P., WOO JOO, S., HANIFEHPOUR, Y., NEJATI-KOSHKI, K., SAMIEI, M., Silver nanoparticles: Synthesis methods, bio-applications and properties, Crit. Rev. Microbiol., 42, No. 2,2016, p. 173.

12. CHI, G. J., YAO, S. W., FAN, J., ZHANG, W. G., WANG, H. Z., Antibacterial activity of anodized aluminum with deposited silver, Surf. Coatings. Technol., 157, No. 2, 2002, p. 162.

13. JAGMINAS, A., ŽALNĖRAVIČIUS, R., RĖZA, A., PAŠKEVIČIUS, A., SELSKIENĖ, A., Design, optical and antimicrobial properties of extremely thin alumina films colored with silver nanospecies, Dalton Trans., 44, 2015, p. 4512.

14. MARAMBIO-JONES, C., HOEK, E. M. V., A review of the antibacterial effects of silver nanomaterials and potential implications for human health and the environment, J. Nanopart. Res., 12, 2010, p. 1531.

15. BERG, T., BOMAN, D., SELGEN, P. O., Induction of tryptophan oxygenase in primary rat liver cell suspensions by glucocorticoid hormone, Exp. Cell Res., 72, 1972, p. 571.

16._EDMONDSON, J. M., ARMSTRONG, L. S., MARTINEZ, A. O., A rapid and simple MTT-based spectrophotometric assay for determining drug sensitivity in monolayer culture, J. Tissue Cult. Meth., 11, 1988, p. 15-17.

17._CHENG, Y. H., CHENG, S. Y., Nanostructures formed by Ag nanowires, Nanotechnology, 15, No. 1, 2003, p. 171.

18. LI, W., ZHOU, J., XU, Y., Study of the in vitro cytotoxicity testing of medical devices, Biomedical Reports, 3, 2015, p. 617.

19. KUNZMANN, A., ANDERSSON, B., THURNHERR, T., KRUG, H., SCHEYNIUS, A., FADEEL, B., Toxicology of engineered nanomedical devices: Focus on biocompatibility, biodistribution and biodegradation, Biochim, Biophys, Acta, 1810, 2011, p. 361.

20. POSKUS, L. T., LIMA, R. S., LIMA, I. R., GUIMARAES, J. G. A., DA SILVA, E. M., GRANJEIRO, J. M. G., Cytotoxicity of current adhesive systems: in vitro testing on cell culture of L929 and balb/c 3T3 fibroblasts, Rev. Odonto Ciênc., 24, No. 2, 2009, p. 129. 
21. SCHMALZ, G., ARENHOLT-BINDSLEV, D., Biocompatibility of Dental Materials, $1^{\text {st }}$ ed., Springer-Verlag, Berlin, 2009, p. 13.

22._AlBUlESCU, R., CODOREAN, E., AlbulESCU, L., CARAENE, G., VUlTURESCU, V., TANASE, C., In vitro biocompatibility testing of implantable biomaterials, Roumanian Biotechnological Letters, 13, No. 4, 2008, p. 3863.

23. WIEGAND, C., HIPLER, U. C., Evaluation of biocompatibility and cytotoxicity using keratinocyte and fibroblast cultures, Skin Pharmacol. Physiol., 22, No. 2, 2009, p. 74.

24. MANTCHEVA, R., KIRADZHIYSKA, D., FEODOROVA, Y., DRAGANOVA, K., Biocompatibility of aluminium alloys and anodic $\mathrm{Al}_{2} \mathrm{O}_{3}$, Bulgarian Chemical Communications, 49, No. 2, 2017 , p. 371.

25. FRESHNEY, R. I., Culture of animal cells: a manual of basic technique and specialized applications, chapter 17 in: Transformation and Immortalization, $6^{\text {th }}$ ed., FRESHNEY, R. I. (Ed.), John Wiley \& Sons, Hoboken, New Jersey, 2010, p. 279.

26. CHENG, X., ZHANG, W., JI, Y., MENG, J., GUO, H., LIU, J., WU, X., XU, H., Revealing silver cytotoxicity using Au nanorods/Ag shell nanostructures: disrupting cell membrane and causing apoptosis through oxidative damage, RSC Adv., 3, 2013, p. 2296

Manuscript received: 25.09 .2020 